\title{
PENGGUNAAN ATRAKTOR UMPAN CACING TANAH (Lumbricus rubellus) TERHADAP HASIL TANGKAPAN BAGAN APUNG DI TELUK PALABUHANRATU
}

\section{Using The Lumbricus rubellus as Bait Attractors due to The Catch of Fish by The Floating Lift Net in Palabuhanratu Bay}

\author{
Oleh : \\ Azhari Imaduddin ${ }^{1}$, Zulkarnain ${ }^{1 *}$, Mokhamad Dahri Iskandar ${ }^{1}$ \\ ${ }^{1}$ Departemen Pemanfaatan Sumberdaya Perikanan, FPIK-IPB \\ *Korespondensi: zulkarnain@apps.ipb.ac.id
}

\begin{abstract}
ABSTRAK
Penelitian ini bertujuan untuk menentukan komposisi hasil tangkapan, frekuensi hauling dan pengaruh atraktor umpan cacing tanah terhadap hasil tangkapan bagan apung. Metode penelitian yang digunakan adalah experimental fishing dengan melakukan kegiatan operasi penangkapan sebanyak 20 kali ulangan (trip) di lapangan. Analisis yang digunakan yaitu analisis deskriptif dan uji Mann Whitney. Hasil penelitian menunjukkan bahwa berat total hasil tangkapan bagan apung perlakuan yakni 1401,1 kg dengan 13 jenis ikan dan bagan apung standar tanpa atraktor umpan 545,5 kg dengan 8 jenis ikan selama 20 ulangan (trip). Selanjutnya untuk melihat adanya perbedaan frekuensi hauling antara kedua bagan apung digunakan uji statistik Mann Whitney yang menunjukkan nilai P value atau Asymp Sig. (2-tailed) $(0.09>0,05)$. Hal ini dapat disimpulkan bahwa tidak adanya perbedaan atau pengaruh yang signifikan terhadap hasil tangkapan kedua bagan apung pada taraf kepercayaan 95\%. Akan tetapi penggunaan atraktor umpan cacing tanah memiliki pengaruh yang signifikan terhadap berat hasil tangkapan bagan apung dengan nilai Asymp Sig. $(2$-tailed $)(0,03<0,05)$ pada taraf kepercayaan 95\%.
\end{abstract}

Kata kunci : Atraktor umpan cacing tanah, kantong umpan, light fishing, komposisi hasil tangkapan bagan apung Palabuhanratu, waktu hauling, jumlah hauling

\begin{abstract}
The purpose of this research is for determine composition of the catch, hauling frequency, and the impact of using the Lumbricus rubellus bait attractors. Used method of this research is experimental fishing by 20 repetitions catch operations in field. The analysis used is descriptive analysis and Mann Whitney test. The researchs's results show that the total weight from the catch of liftnet with the treats is $1401,1 \mathrm{~kg}$ with $13 \mathrm{kind}$ of fish and 545,5 $\mathrm{kg}$ from standard lift net that not used bait attractors got 8 kind of fish for 20 trips of catching operation. Next, to see the different of hauling frequencies between the both of lift net is used the Mann Whitney test and show the P value or Asymp Sig. (2-tailed) (0,09 $>0,05)$. It means there wasn't significance different on hauling frequencies from both of lift net on significance level $95 \%$. But using of Lumbricus rubellus there was significance effect on the catch from lift net with the Asymp Sig. (2-tailed) value (0,03 > 0,05) on the significance level 95\%.
\end{abstract}

Keywords : Lumbricus rubellus bait attractors, bait bag, light fishing, catch composition of Palabuhanratu floating lift net, time of hauling, hauling frequencies

\section{PENDAHULUAN}

Teluk Palabuhanratu merupakan perairan dikenal memiliki potensi sumberdaya ikan yang cukup melimpah dan memiliki peluang pengembangan yang besar sebagai daerah untuk melakukan 
usaha penangkapan ikan, hal tersebut dikarenakan lokasi Teluk Palabuhanratu sangat strategis dan menghadap ke Samudera Hindia. Salah satu usaha penangkapan yang dapat dilakukan yaitu dengan menggunakan alat tangkap bagan apung. Hal ini ditunjukkan oleh banyaknya alat tangkap bagan apung yang tersebar di perairan Teluk Pelabuhanratu.

Bagan apung (lift net) merupakan alat tangkap yang dioperasikan pada malam hari. Alat tangkap ini menggunakan atraktor cahaya (lampu) buatan. Atraktor cahaya yang digunakan berfungsi untuk mengumpulkan ikan yang bersifat fototaksis positif. Ikan yang bersifat fototaksis positif akan berkumpul di daerah cahaya lampu sehingga membantu nelayan dalam upaya melakukan penangkapan (Hasan 2008). Beberapa penelitian bagan sebelumnya banyak penerapan teknologi-teknologi yang dapat meningkatkan optimalisasi penangkapan ikan, diantaranya adalah penggunaan lampu LED dan lampu bawah air. Untuk meningkatkan jumlah hasil tangkapan tidak hanya diperlukan adanya pengembangan teknologi, tetapi juga digunakan alat bantu penangkapan ikan, seperti penggunaan atraktor rumpon pada bagan apung (Zulkarnain 2002). Dengan pendekatan fungsi yang sama seperti atraktor rumpon, maka atraktor umpan diduga juga bisa meningkatkan jumlah hasil tangkapan ikan pada alat tangkap bagan apung. Pada penelitian kali ini dilakukan penambahan alat bantu berupa atraktor umpan cacing tanah yang diduga dapat memaksimalkan hasil tangkapan alat tangkap bagan apung.

Cacing Tanah (Lumbricus rubellus) tergolong ke dalam hewan avertebrata (tidak bertulang belakang) sehingga sering disebut binatang lunak (Palungkung 1999). Menurut Rukmana (1999), panjang tubuh cacing tanah antara $8 \mathrm{~cm}-14 \mathrm{~cm}$ dengan jumlah segmen 95-100 segmen. Gerakannya lamban dan kadar air tubuh cacing tanah berkisar 70\%-78\%. Alasan penggunaan umpan cacing tanah yaitu karena cacing tanah sangat potensial dengan kandungan nutrisinya cukup tinggi, dimana komposisi kimia cacing tanah (g/100g), yaitu energi 110,50 kalori; kandungan protein 19,77; lemak 2,48; karbohidrat 2,25; air 72,69 dan abu 2,93 (Raharti 1999; Soenanto 2000), dan sebagai umpan ikan (Sihombing 1999). Selain itu cacing tanah juga mengandung asam amino esensial seperti arginine, histidin, isoleusin, leusin, lisin, metionin, fenilalani, treonin dan valin. Asam amino non esensial seperti sistin, glisin, serin, dan tirosin (Palungkung 1999). Kandungan dari asam amino tersebut diidentifikasi sebagai perangsang nafsu makan ikan (Riyanto 2008).

Penelitian tentang penggunaan atraktor umpan cacing tanah dilakukan karena adanya dugaan pada saat kegiatan hauling bagan apung dan jaring terangkat ke arah permukaan air, ikan-ikan yang sudah terkumpul di daerah cakupan tangkapan (catchable area) jaring akan melarikan diri (fish escaping) menjauhi bagan apung. Oleh karena itu, penggunaan atraktor umpan cacing tanah ini dimaksudkan agar ikan-ikan yang telah melarikan diri tidak pergi menjauhi bagan apung dan dengan mudah berkumpul kembali dekat dengan sumber cahaya saat dilakukan setting jaring berikutnya.

Tujuan dilakukannya penelitian yaitu sebagai berikut menentukan komposisi hasil tangkapan alat tangkap bagan apung penelitian, yaitu bagan apung yang menggunakan atraktor umpan cacing tanah (Lumbricus rubellus) dan bagan apung tanpa atraktor umpan yang biasa nelayan gunakan di Teluk Palabuhanratu, dan menentukan pengaruh penggunaan atraktor umpan cacing tanah terhadap hasil tangkapan pada bagan apung penelitian, serta menentukan frekuensi hauling bagan apung penelitian

\section{METODE PENELITIAN}

Penelitian dilakukan pada bulan Juli 2018 yang bertempat di Teluk Palabuhanratu, Kabupaten Sukabumi, Provinsi Jawa Barat.

Penelitian ini merupakan uji coba penangkapan (experimental fishing) dengan melakukan kegiatan operasi penangkapan secara langsung di lapangan. Penelitian ini membandingkan hasil tangkapan alat tangkap bagan apung (lift net) dengan diberi perlakuan berupa pemasangan atraktor 
umpan dalam kantong umpan yang berisi cacing tanah dengan bagan apung standar milik nelayan yang tidak dipasang umpan. Kedua bagan apung memiliki spesifikasi yaitu ukuran yang sama dan memiliki 12 lampu yang berdaya 45 watt dan 1 lampu celup bawah air (lacuba) berdaya 45 watt. Pada kegiatan Experimental fishing bagan penelitian yang menggunakan atraktor umpan cacing tanah dengan bagan standar dilakukan dalam waktu bersamaan. Sebelum melakukan uji coba penangkapan, dilakukan terlebih dahulu prapenelitian. Berdasarkan prapenelitian didapatkan kedalaman kantung umpan yang optimal yaitu pada kedalaman $3 \mathrm{~m}$. Pengambilan data dilakukan sebanyak 20 Ulangan. Pada penelititan ini trip penangkapan diperlakukan sebagai ulangan. Menurut Roscoe (1975) untuk penelitian eksperimental, penelitian yang sukses adalah dengan ukuran sampel atau ulangan 10 sampai dengan 20. Bagan alir penelitian dapat dilihat pada (Gambar 1) dan desain kantong umpan dapat dilihat pada (Gambar 2).

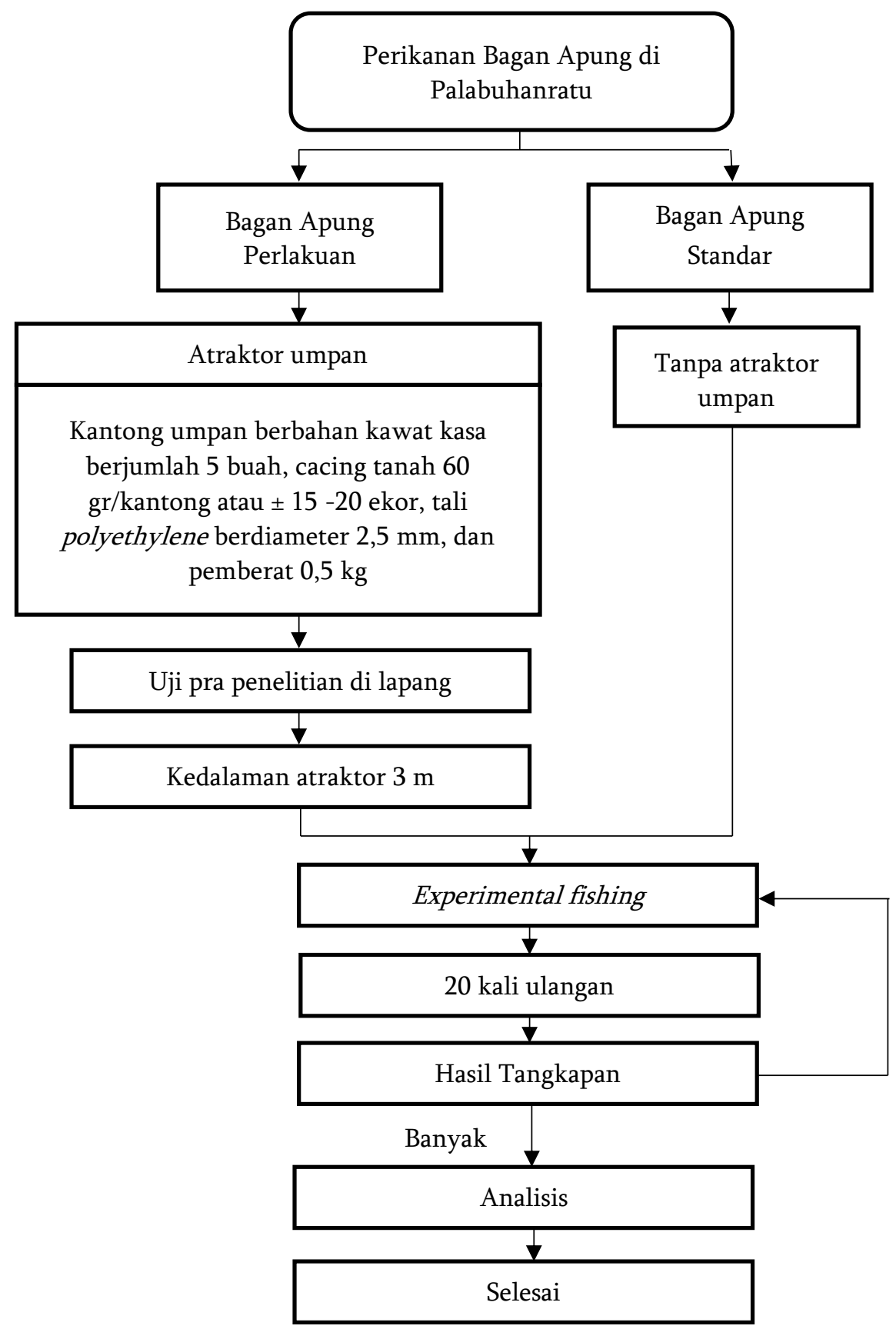

Sedikit

Gambar 1 Bagan Alir Penelitian 


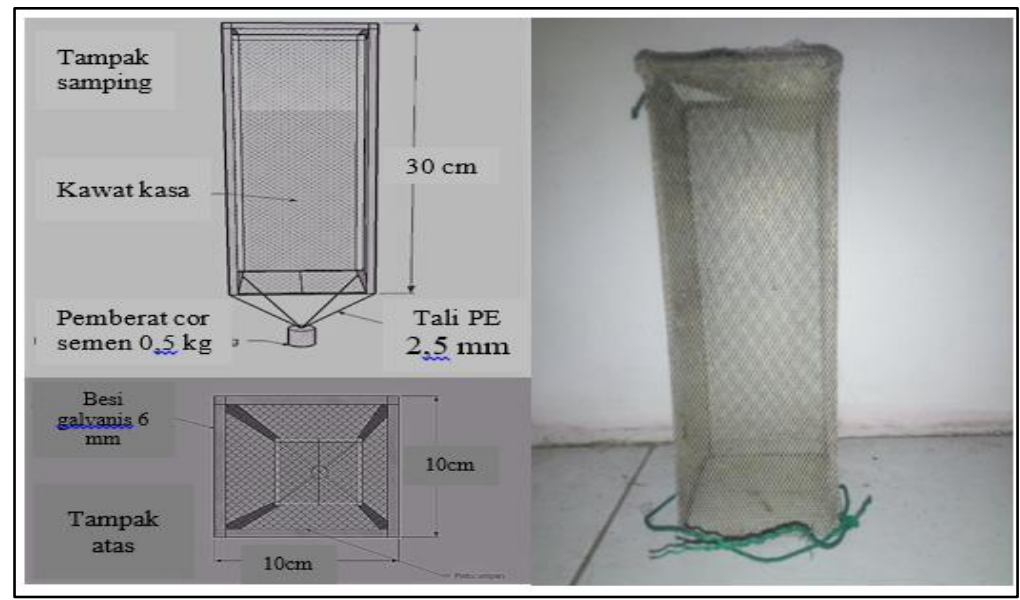

Gambar 2 Atraktor Kantong Umpan

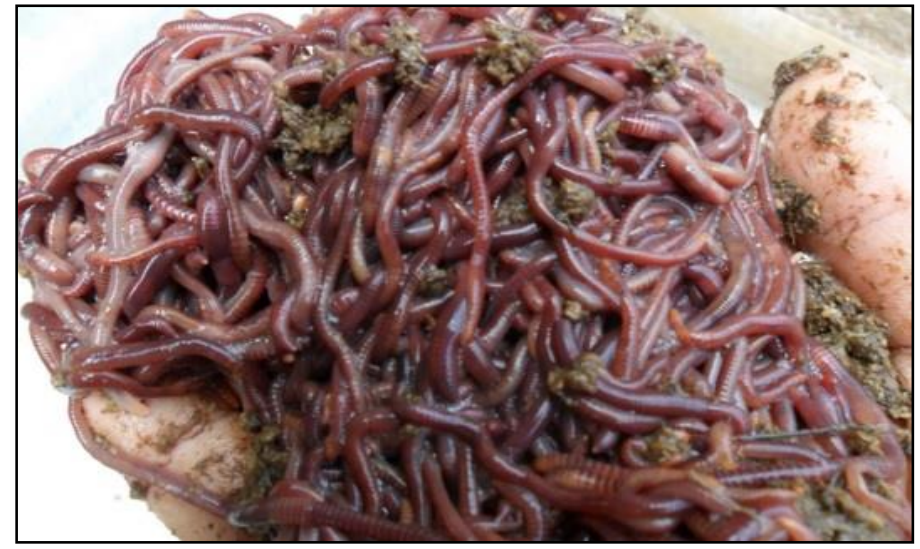

Gambar 3 Umpan Cacing Tanah

Data yang dikumpulkan berupa data primer. Data primer diperoleh dengan cara melakukan pengamatan langsung di lapangan dengan melihat perbandingan hasil tangkapan antara bagan apung penelitian yang dipasang atraktor kantong umpan cacing tanah dengan bagan apung standar. Data yang dikumpulkan adalah:

1. Waktu setting yaitu waktu yang dicatat saat lampu bagan mulai dinyalakan dan jaring diturunkan ke dalam air pada bagan apung penelitian.

2. Waktu hauling yaitu waktu yang dicatat saat sebagian lampu dimatikan sampai tersisa satu lampu yang masih menyala dan jaring ditarik ke permukaan air pada bagan apung penelitian.

3. Jumlah hauling yaitu frekuensi penarikan jaring dalam setiap trip penangkapan ikan pada bagan apung penelitian dan bagan apung standar.

4. Jenis ikan hasil tangkapan per trip penangkapan pada bagan apung penelitian dan bagan apung standar.

5. Berat total ikan hasil tangkapan per hauling pada bagan apung penelitian.

6. Suhu permukaan air laut diukur menggunakan termometer batang yang dicelupkan di dalam air laut dan didiamkan selama 1 menit, kemudian dilakukan pengukuran sebanyak 3 kali ulangan untuk setiap trip penangkapan.

Atraktor umpan cacing tanah yang digunakan pada penelitian ini sebanyak 5 buah. Penempatan 4 buah atraktor umpan diletakkan pada setiap sudut bagan apung penelitian, sisanya 1 buah diletakkan di dekat sumber cahaya yaitu di tengah bagan dengan kedalaman $3 \mathrm{~m}$ dari atas permukaan air. Peletakkan atraktor umpan tersebut diduga optimal dikarenakan posisi tersebut merupakan daerah cakupan tangkapan (catcable area) dari jaring bagan. Penempatan posisi atraktor umpan cacing tanah. 


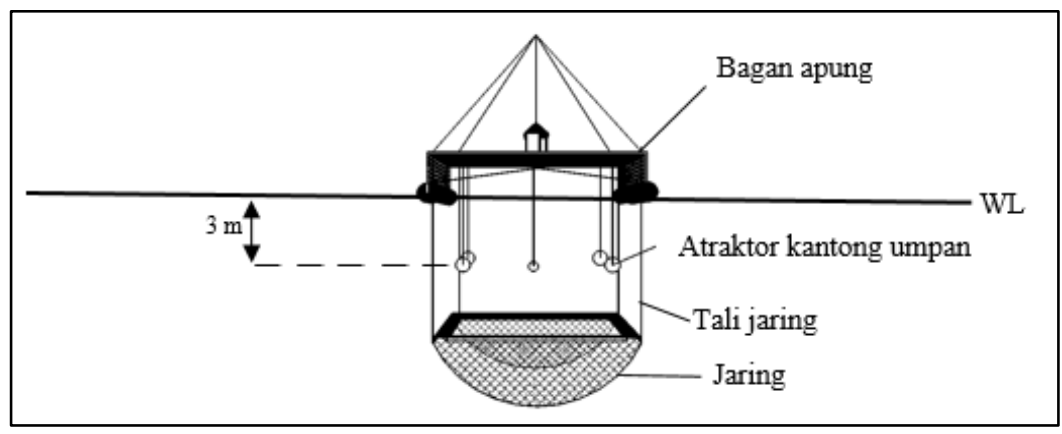

Gambar 4 Penempatan Kantong Umpan

Data hasil tangkapan disajikan dalam bentuk tabel beserta diagram, kemudian dianalisis secara deskriptif menurut pokok-pokok pembahasan seperti komposisi total hasil tangkapan bagan apung, hasil tangkapan pada bagan apung yang menggunakan atraktor umpan cacing tanah (Lumbricus rubellus) dan bagan apung standar tanpa umpan, serta jenis ikan dominan yang tertangkap berdasarkan berat total selama 20 kali trip penangkapan.

Uji ini dilakukan terhadap berat total hasil tangkapan bagan apung yang menggunakan atraktor umpan cacing tanah dan bagan apung standar tanpa atraktor umpan berdasarkan berat total $(\mathrm{kg})$ serta analisis terhadap frekuensi hauling kedua bagan apung tersebut. Adapun dasar keputusan yang akan diambil dalam uji ini adalah:

a. Jika nilai P value atau Asymp Sig. $(2$-tailed $)<(\alpha)$ maka tolak H0, berarti bagan penelitian dengan bagan standar memiliki perbedaan yang signifikan terhadap hasil tangkapan.

b. Jika nilai P value atau Asymp Sig. $(2$-tailled $)>(\alpha)$ maka gagal tolak H0, berarti bagan penelitian dengan bagan standar tidak memiliki perbedaan yaang signifikan terhadap hasil tangkapan.

Hipotesis atau kesimpulan yang akan diambil:

H0: Tidak terdapat perbedaan hasil tangkapan antara kedua bagan apung

H1: Terdapat perbedaan hasil tangkapan antara kedua bagan apung

\section{HASIL DAN PEMBAHASAN}

\section{Komposisi Total Hasil Tangkapan Kedua Bagan Apung}

Hasil tangkapan bagan apung yang dioperasikan sebanyak 20 kali ulangan terdiri dari 13 jenis ikan hasil tangkapan.

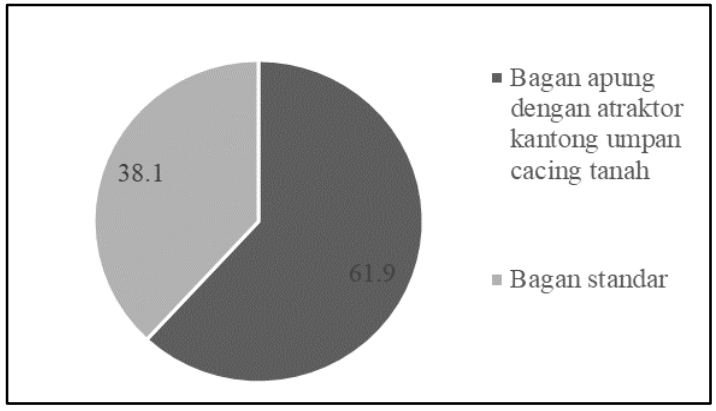

Gambar 5 Persentase Hasil Tangkapan Ikan Pelagis pada Kedua Bagan Apung

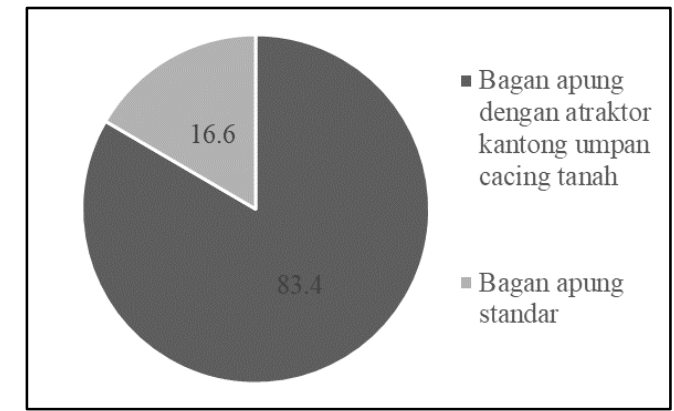

Gambar 6 Persentase Hasil Tangkapan Ikan Demersal pada Kedua Bagan 
Tabel 1 Komposisi ikan hasil tangkapan kedua bagan apung.

\begin{tabular}{|c|c|c|c|c|c|c|c|c|}
\hline $\begin{array}{l}\text { Jenis } \\
\text { Ikan }\end{array}$ & No & $\begin{array}{l}\text { Nama } \\
\text { Lokal }\end{array}$ & Nama Inggris & Nama Latin & $\begin{array}{c}\text { Bagan } \\
\text { apung } \\
\text { dengan } \\
\text { umpan } \\
\text { cacing } \\
\text { tanah } \\
(\mathrm{Kg})\end{array}$ & (\%) & $\begin{array}{l}\text { Bagan } \\
\text { apung } \\
\text { standar }\end{array}$ & (\%) \\
\hline \multirow{7}{*}{$\begin{array}{l}\text { Jenis } \\
\text { Ikan } \\
\text { Pelagis }\end{array}$} & 1 & Tembang & Sardine & Sardinella $s p$ & 348.5 & 24.9 & 149 & 27.3 \\
\hline & 2 & Lisong & Mackerel & Auxis sp & 118.5 & 8.5 & 159 & 29.1 \\
\hline & 3 & Teri & $\begin{array}{l}\text { Commerson's } \\
\text { anchovy }\end{array}$ & $\begin{array}{l}\text { Stolephorus } \\
s p\end{array}$ & 55.3 & 3.9 & 42 & 7.7 \\
\hline & 4 & Layang & Russell's scad & $\begin{array}{l}\text { Decapterus } \\
\text { russelli }\end{array}$ & 51.5 & 3.7 & 42 & 7.7 \\
\hline & 5 & Cumi & Squid & Loligo sp & 28.9 & 2.1 & 2 & 0.4 \\
\hline & 6 & Bilis & $\begin{array}{l}\text { Indian } \\
\text { anchovy }\end{array}$ & $\begin{array}{l}\text { Stolephorus } \\
\text { indicus }\end{array}$ & 30.1 & 2.1 & 0 & 0.0 \\
\hline & 7 & Japuh & $\begin{array}{l}\text { Rainbow } \\
\text { sardine }\end{array}$ & $\begin{array}{l}\text { Dussumieria } \\
\text { acuta }\end{array}$ & 7.0 & 0.5 & 0 & 0.0 \\
\hline & Subtotal & & & & 639.8 & 45.7 & 394 & 72.2 \\
\hline \multirow{8}{*}{$\begin{array}{c}\text { Jenis } \\
\text { Ikan } \\
\text { Demersal }\end{array}$} & 1 & Semar & Moonfish & $\begin{array}{l}\text { Mene } \\
\text { maculata }\end{array}$ & 404.0 & 28.8 & 0 & 0.0 \\
\hline & 2 & Layur & $\begin{array}{l}\text { Common } \\
\text { hairtail }\end{array}$ & Trichiurus $s p$ & 243.3 & 17.4 & 55.5 & 10.2 \\
\hline & 3 & Pepetek & Pony fish & $\begin{array}{l}\text { Leiognathus } \\
\text { equulus }\end{array}$ & 105.5 & 7.5 & 86 & 15.8 \\
\hline & 4 & Rebon & $\begin{array}{l}\text { Acetes } \\
\text { shrimp }\end{array}$ & Acetes sp & 3.0 & 0.2 & 10 & 1.8 \\
\hline & 5 & Swanggi & $\begin{array}{l}\text { Purple- } \\
\text { spotted big } \\
\text { eye }\end{array}$ & $\begin{array}{l}\text { Priacanthus } \\
\text { tayanus }\end{array}$ & 4.0 & 0.3 & 0 & 0.0 \\
\hline & 6 & Jalidin & Butter fish & $\begin{array}{l}\text { Lepidocybium } \\
s p\end{array}$ & 1.5 & 0.1 & 0 & 0.0 \\
\hline & Subtotal & & & & 761.3 & 54.3 & 151.5 & 27.8 \\
\hline & Total & & & & 1401.1 & 100.0 & 545.5 & 100.0 \\
\hline
\end{tabular}

Berdasarkan komposisi hasil tangkapan dari kedua bagan apung diperoleh hasil tangkapan bagan apung dengan atraktor kantong umpan cacing tanah lebih tinggi serta memiliki keanekaragaman jenis ikan lebih banyak dibandingkan bagan apung standar yang tidak memakai atraktor umpan. Bagan apung yang menggunakan atraktor umpan cacing tanah memiliki berat total hasil tangkapan sebanyak 20 kali ulangan sebesar $1401.1 \mathrm{~kg}$, sedangkan bagan apung standar yang tidak memakai atraktor umpan memiliki berat total sebanyak 20 kali ulangan sebesar $545.5 \mathrm{~kg}$.

\section{Komposisi Hasil Tangkapan Berdasarkan Jenis Ikan}

Terdapat 5 jenis hasil tangkapan tertinggi, yaitu ikan tembang (Sardinella sp), semar (Mene maculate), layur (Trichiurus savala), tongkol lisong (Auxis sp), dan pepetek (Leiognathus equulus). Ikan tembang adalah jenis ikan terbanyak yang tertangkap pada kedua bagan apung tersebut. Terhitung sebanyak 348,5 kg didapatkan oleh bagan penelitian dan $149 \mathrm{~kg}$ didapatkan oleh bagan standar. Hal ini disebabkan melimpahnya jenis ikan tembang pada daerah tersebut yang dikarenakan faktor suhu 
permukaan laut yang berkisar $28-30^{\circ} \mathrm{C}$ sebab ikan pelagis kecil dapat beradaptsi pada kisaran suhu tersebut (Rasyid 2010). Kemudian adanya kemungkinan terangsangnya organ penciuman ikan karena adanya asam amino yang dimiliki oleh cacing tanah sehingga ikan datang menghampiri.

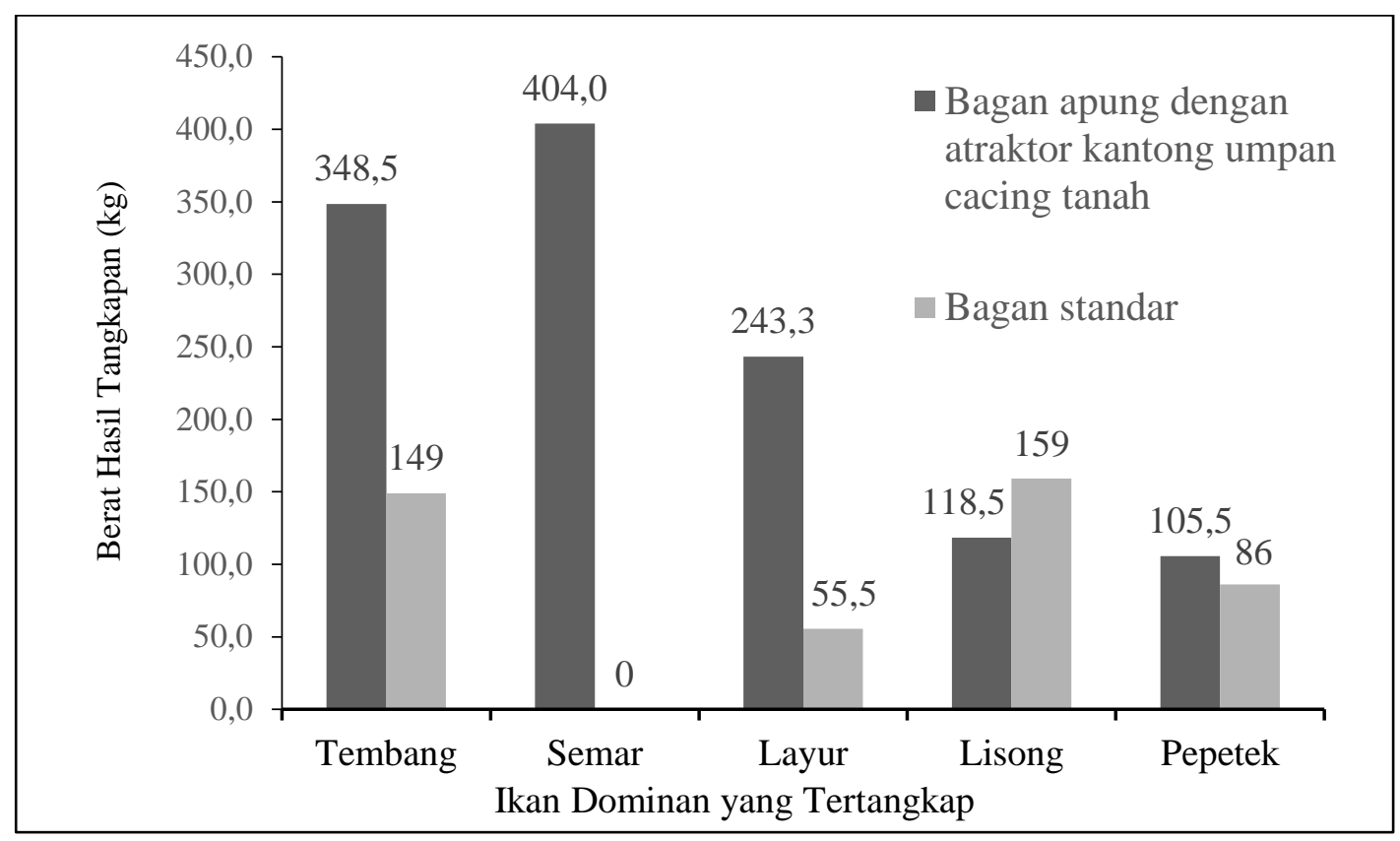

Gambar 7 Perbandingan hasil tangkapan ikan dominan.

Selanjutnya ada ikan semar yang memiliki berat total $404 \mathrm{~kg}$ hanya diperoleh dari bagan dengan atraktor umpan cacing tanah. Dalam 20 kali ulangan (trip) hanya didapat 4 kali ulangan saja. Berdasarkan penelitian sebelumnya ikan semar tidak hanya jenis ikan fototaksis positif, tetapi juga tertarik karena umpan (Pangalila F et al 2014). Hal itu yang dapat menyebabkan jenis ikan semar hanya didapatkan oleh bagan apung yang menggunakan atraktor umpan cacing tanah.

Pada urutan ketiga ada ikan layur 243,1 kg diperoleh dari bagan dengan atraktor umpan cacing tanah dan 55,5 kg diperoleh dari bagan standar. Jenis ikan layur paling sering tertangkap, terhitung sebanyak 14 kali ulangan selalu tertangkap. Jenis ikan ini memiliki migrasi vertikal diurnal yang berlawanan saat dewasa dan juvenil saat mencari makan. Ikan layur dewasa pada umumnya mencari makan dekat permukaan perairan sepanjang siang hari dan migrasi ke dasar perairan saat malam. Juvenil membentuk kelompok-kelompok pada daerah $100 \mathrm{~m}$ di atas dasar perairan sepanjang siang hari dan membentuk kelompok untuk mencari makan saat malam hari di permukaan perairan (Vianita $\mathrm{R}$ et al 2014). Hal ini menyebabkan melimpahnya hasil tangkapan layur yang masih juvenil dibandingkan layur dewasa. Faktor lain yang mempengaruhi bisa dikarenakan asam amino yang ada dalam cacing tanah yang merangsang ikan-ikan pelagis kecil seperti tembang, semar, dan teri untuk mendatangi sumber bau amis dari cacing tanah, sehingga ikan layur yang merupakan predator naik ke permukaan air untuk mencari makan.

Urutan keempat ada ikan tongkol lisong, sebanyak 118, $5 \mathrm{~kg}$ tertangkap pada bagan dengan atraktor umpan cacing tanah dan sebanyak $159 \mathrm{~kg}$ pada bagan standar. Ikan tongkol merupakan ikan yang termasuk pelagis besar (Simbolon 201). Jenis ikan ini hanya didapatkan pada 4 ulangan saja dikarenakan tongkol lisong bermigrasi secara horizontal dan sulit tertangkap dengan alat tangkap bagan apung, serta jenis ikan ini termasuk fototaksis positif dan lebih mengandalkan indera penglihatan untuk mencari makanan.

Jenis ikan dengan hasil tangkapan tertinggi terakhir adalah ikan pepetek. Sebanyak 105,5 kg tertangkap pada bagan dengan atraktor umpan cacing tanah dan sebanyak $86 \mathrm{~kg}$ tertangkap pada bagan standar. Jenis ikan ini tertngkap sebanyak 13 trip. Pepetek hidup di lingkungan bentopelagik (dasar 
perairan hingga mencapai permukaan) sebagian besar hidup di laut, beberapa di air payau dan air tawar (Dewi $\mathrm{N}$ et al 2016). Ikan pepetek hidup pada kedalaman 10-110 m, dan biasanya ditemukan dalam gerombolan besar (Novitriana 2004). Oleh sebab itu jenis ikan ini sering tertangkap pada kedua bagan apung penelititan. Menurut Stoner (2004) bahwa pada kebanyakan kasus, ikan akan tertarik umpan melalui isyarat kimia pada saat kondisi cahaya kurang tetapi organ penglihatan sangat berperan ketika lokasi umpan dekat dengan posisi ikan dan akhirnya memakan umpan/makanan tersebut, sehingga pada keadaaan malam hari organ sensorik yang lebih berperan adalah organ penciuman ketika posisi umpan jauh, namun ketika posisi umpan dekat dengan ikan organ penglihatanlah yang lebih berperan.

Tingkah laku ikan terhadap umpan memiliki respon yang berbeda-beda. Hal ini diakibatkan oleh organ sensori ikan, yaitu organ penglihatan, penciuman serta gurat sisi. Pada organ penciuman ikan, menurut Carton dan Montgomery (2003) bau yang diterima organ penciuman akan mengkondisikan rheotaxis bau (makanan) tanpa melakukan penyeleksian terhadap informasi bau tersebut sebagai suatu isyarat yang kompleks.

\section{Hasil Uji Mann Whitney terhadap Berat Total Hasil Tangkapan}

Berdasarkan uji Mann Whitney terhadap berat total hasil tangkapan antara bagan apung yang menggunakan atraktor kantong umpan cacing tanah dan bagan standar diperoleh nilai Sig. (2-tailed) < $0,05(0.03<0,05)$. Hal ini menunjukkan bahwa ada perbedaan yang signifikan terhadap hasil tangkapan bagan apung penelitian yang menggunakan atraktor umpan cacing tanah dengan bagan apung standar tanpa umpan pada selang kepercayaan 95\%. Dapat diartikan juga bahwa adanya pengaruh penggunaan atraktor umpan cacing tanah yang mendapatkan hasil tangkapan lebih banyak dibandingkan tanpa menggunakan atraktor umpan.

\section{Perbedaan Berat Total Ikan Tertangkap pada Bagan Apung dengan Atraktor Kantong Umpan Cacing Tanah terhadap Waktu Hauling}

Berdasarkan dari waktu hauling bagan apung dengan atraktor kantong umpan cacing tanah terhitung berat total hasil tangkapan pada pukul $18.00-24.00$ sebanyak $643,65 \mathrm{~kg}$ atau sekitar $46 \%$ dari berat total seluruh hasil tangkapan, sedangkan pada pukul 00.00-06.00 diperoleh hasil tangkapan dengan berat total 757,4 kg atau sekitar 54 \% dari berat total hasil tangkapan dalam 20 kali ulangan. Jenis ikan seperti ikan semar, tembang, layur, pepetek, teri, layang, bilis, cumi, japuh, swanggi, dan rebon lebih sering tertangkap pada pukul 00.00-06.00. Sedangkan jenis ikan seperti ikan tongkol lisong dan gindara lebih sering tertangkap pada waktu 18.00-24.00. Hal ini menunjukkan waktu hauling bagan apung paling optimal adalah setelah tengah malam 00.00-06.00 (Dwipayana et al 2018).

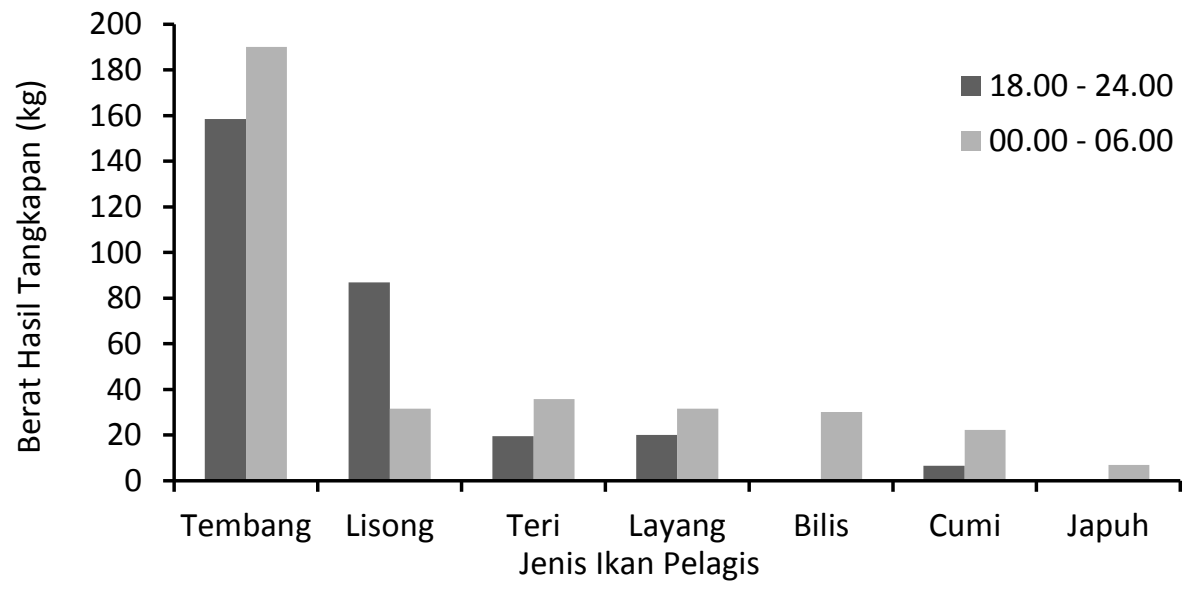

Gambar 8 Berat total hasil tangkapan ikan pelagis berdasarkan perbedaan waktu hauling 


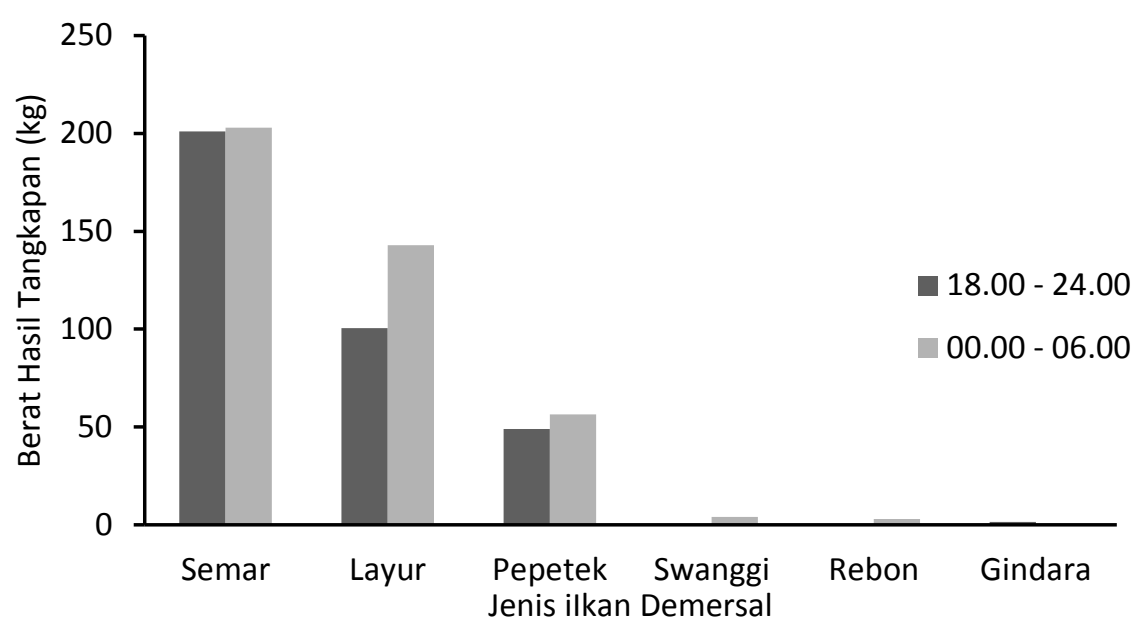

Gambar 9 Berat total hasil tangkapan ikan demersal berdasarkan perbedaan waktu hauling

\section{Perbedaan Hauling Bagan dengan Atraktor Kantong Umpan Cacing Tanah terhadap Waktu Penangkapan}

Jumlah hauling pengangkatan jaring berbeda-beda pada setiap waktunya. Pada pukul 18.0024.00 jumlah hauling sebanyak 33 kali sedangkan pukul 00.00-06.00 sebanyak 38 kali. Bagan apung dengan atraktor kantong umpan cacing tanah memiliki rata-rata hauling terbanyak pada pukul 00.0006.00 dengan nilai rata-rata \pm SE adalah 1,9 kali $\pm 0,19$. Hauling pada pukul 18.00-24.00 memiliki nilai rata-rata \pm SE sebesar 1,65 kali $\pm 0,15$.

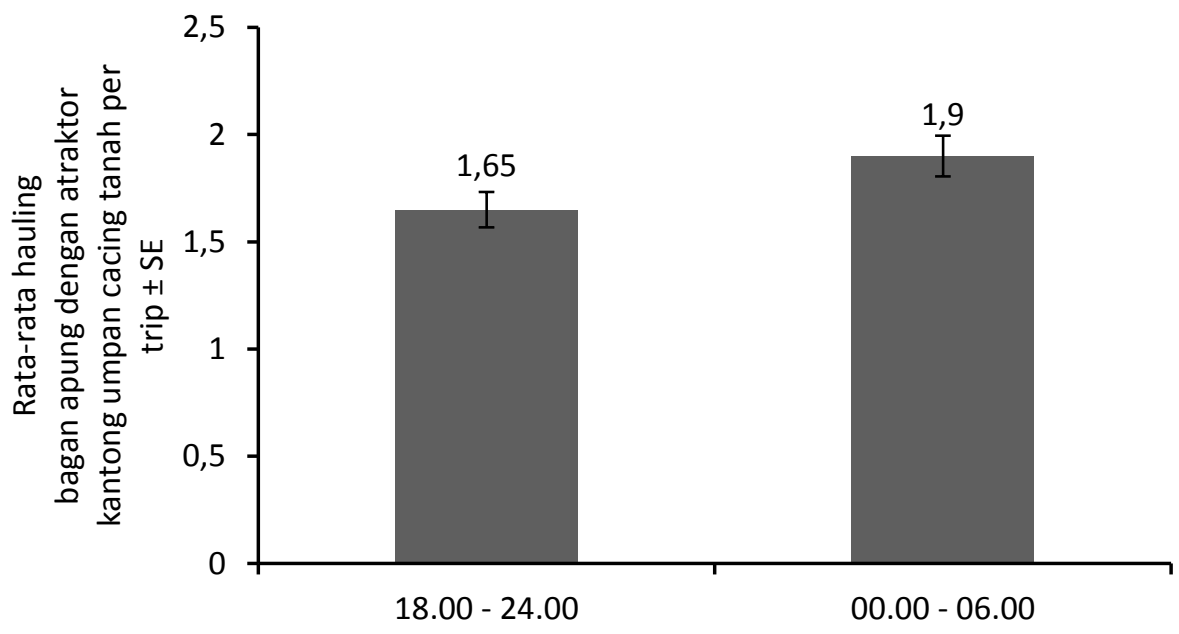

Gambar 10 Rata-rata hauling bagan apung dengan atraktor kantong umpan cacing tanah $\pm \mathrm{SE}$

Perbedaan Hauling Bagan Apung dengan Atraktor Kantong Umpan Cacing Tanah dan Bagan Apung Standar

Bagan apung dengan atraktor kantong umpan cacing tanah memiliki total jumlah hauling sebanyak 71 kali, sedangkan bagan standar memiliki total jumlah hauling sebanyak 62 kali. Bagan apung dengan atraktor kantong umpan cacing tanah memiliki rata-rata hauling terbanyak dengan nilai rata-rata \pm SE adalah 3,55 $\pm 0,18$ sedangkan bagan standar memiliki nilai rata-rata \pm SE adalah 3,1 \pm 0,19. Grafik nilai-rata frekuensi hauling dapat dilihat pada Gambar 11. 


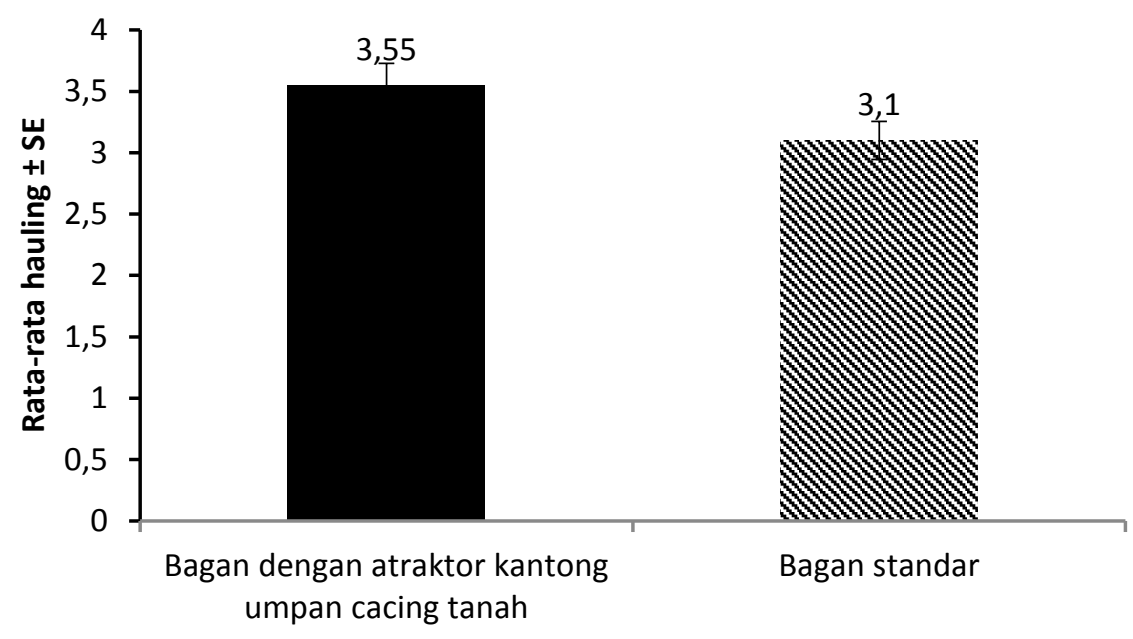

Gambar 11 Rata-rata hauling kedua bagan apung \pm SE.

\section{Hasil analisis uji Mann Whitney berdasarkan frekuensi hauling}

Berdasarkan uji Mann Whitney terhadap hauling antara kedua bagan didapatkan nilai $\mathrm{P}$ atau Sig. (2-tailed) 0,09. Hal ini menunjukkan bahwa Sig. $(2$-tailed $)>\alpha,(0,09>0,05)$ yang artinya hauling bagan apung penelitian yang menggunakan atraktor kantong umpan cacing tanah tidak berbeda secara signifikan dengan bagan standar tanpa atraktor umpan pada selang kepercayaan $95 \%$.

\section{KESIMPULAN DAN SARAN}

\section{Kesimpulan}

1. Komposisi total hasil tangkapan pada alat tangkap bagan apung yang menggunakan atraktor umpan cacing tanah terdiri dari 13 jenis ikan yaitu ikan tembang (Sardinella sp), semar (Mene macullata), layur (Trichiurus savala), lisong (Auxis sp), pepetek (Leiognathus equulus), teri (Stolephorus sp), layang (Decapterus ruselli), cumi (Loligo sp), bilis (Thryssa hamiltoni), rebon (Acetes $s p$ ), japuh (Dussumieria acuta), swanggi (Priacanthus tayanus), dan jalidin/gindara (Lepidocybium flavobrunneum). Sedangkan bagan apung standar yang tidak menggunakan atraktor umpan hanya mendapatkan 8 jenis ikan hasil tangkapan yaitu, ikan tembang, layur, lisong, pepetek, teri, layang, cumi, dan rebon.

2. Berat total hasil tangkapan bagan apung dengan atraktor umpan cacing tanah dan bagan apung tanpa atraktor umpan memiliki perbedaan yang nyata.

3. Frekuensi hauling antara kedua bagan apung tidak memiliki perbedaan yang nyata.

\section{Saran}

Mempertimbangkan penggunaan umpan cacing tanah sebagai alternatif atraktor umpan kepada nelayan bagan apung sebagai implementasi paket teknologi tepat guna.

\section{DAFTAR PUSTAKA}

Carton AG, Montgomery JC. 2003. Evidance of a rheotactic component in the odour search behaviour of freshwater eels. Journal of Fish Biology (62): 501-516.

Dewi N, Kamal M, Wardiatno Y. 2016. Variasi spasial dan temporal biomassa komunitas ikan di perairan pesisir Kabupaten Tangerang, Banten. Jurnal Ilmu dan Teknologi Kelautan Tropis. 8(1): $39-55$. 
Dwipayana M F, Sunarto, Rostini I, Apriliani I M. 2018. Hasil tangkapan alat tangkap bagan apung dengan waktu hauling berbeda di Pantai Timur Perairan Pangandaran. Jurnal Perikanan dan Kelautan. 9(1): 112-118.

Fitri Aristia DP. 2008. Respon Penglihatan dan Penciuman Ikan Kerapu (Serranidae) terhadap Umpan dalam Efektifitas Penangkapan. [Disertasi]. Bogor (ID): Institut Pertanian Bogor.

Gunarso W. 1985. Suatu Pengantar tentang Tingkah Laku Ikan Terutama dalam Hubungannya dengan Alat Metode dan Taktik Penangkapan. Bogor (ID). Institut Pertanian Bogor.

Hasan. 2008. Uji Coba Penggunaan Lampu Lacuba Tenaga Surya terhadap Hasil Tangkapan Ikan Di Pelabuhan Ratu. Jawa Barat. Jurnal Sains dan Teknologi Indonesia Volume 2, Nomor 3 (Juni 2000), hal 11-18.

Novitriana R, Ernawati, M F Rahardjo. 2004. Aspek pemijahan ikan petek Leiognathus equulus, Forsskal 1775 (fam. Leiognathidae) di pesisir Mayangan Subang, Jawa Barat. Jurnal Ikhtiologi Indonesia. 4(1): 413-417.

Palungkung R. 1999. Sukses Beternak Cacing tanah Lumbricus rubellus.Jakarta (ID). Penebar Swadaya.

Pangalila F P T, Budiman J, Telleng A T R, Reppie E. 2014. Kajian perikanan tangkap Mene maculate di Teluk Buyat. Jurnal IPTEKS PSP. 1(2): 103-111.

Rasyid A. 2010. Distribusi suhu permukaan pada musim perairan Barat-Timur terkait dengan fishing ground ikan pelagis kecil di Perairan Spermonde. Torani (Jurnal Ilmu Kelautan dan Perikanan, Fakultas Kelautan dan Perikanan, Univeristas Hassanudin, Makassar). 20(1): 1-7.

Riyanto M. 2008. Respon Penciuman Ikan Kerapu Macan (Epinephelus fuscoguttatus) Terhadap Umpan Buatan [Tesis]. Bogor (ID): Program Pascasarjana, Institut Pertanian Bogor.

Rukmana R H. 1999. Budidaya Cacing Tanah. Yogyakarta (ID). Kanisius.

Roscoe, J T. 1975. Fundamental Research Statistic for The Behavior Sciencess. New York (US).

Sihombing DTH. 1999. Satwa Harapan I : Pengantar Ilmu dan Tehnologi Budidaya. Bogor (ID). Pustaka Wirausaha Muda.

Simbolon D, Harry SG. 2009. Hubungan antara kandungan klorofil-a dengan hasil tangkapan ikan tongkol di daerah penangkapan ikan perairan Palabuhanratu. Jurnal Penelitian Perikanan Indonesia. Jakarta (ID): Pusat Riset Perikanan Tangkap.

Soenanto H. 2000. Budidaya Cacing Tanah (Lumbricus rubellus). Solo (ID). CV. Aneka.

Vianita R, Saputra S W, Solichin A. 2014. Aspek biologi ikan layur (Trichiurus lepturus) berdasarkan hasil tangkapan di PPP Morodemak. Jurnal Manajemen Sumberaya Perairan UNDIP. 3(3): 160167.

Zulkarnain. 2002. Studi tentang penggunaan rumpon pada bagan apung di Teluk Palauhanratu, Jawa Barat [Tesis]. Bogor (ID): Institut Pertanian Bogor. 